\title{
- PROCES KSZTAŁCENIA PIELĘGNIAREK I POŁOŻNYCH W ŚWIETLE WYBRANYCH DANYCH STATYSTYCZNYCH
}

\section{THE PROCESS OF NURSES AND MIDWIVES' EDUCATION IN LIGHT OF SELECTED STATISTICAL DATA}

\author{
Renata Rasińska1, Iwona Nowakowska', Agnieszka Bańkowska² \\ ' Zakład Organizacji i Zarządzania w Opiece Zdrowotnej, \\ Uniwersytet Medyczny im. Karola Marcinkowskiego w Poznaniu \\ ${ }^{2}$ Zakład Higieny i Epidemiologii \\ Collegium Medicum w Bydgoszczy UMK w Toruniu
}

DOI: https://doi.org/10.20883/pielpol.2017.45

\begin{abstract}
STRESZCZENIE
Pożądana, wysoka jakość pracy w podmiotach działalności leczniczej możliwa jest do osiągnięcia tylko wówczas, gdy zagwarantowany zostanie wysoki poziom świadczonych usług medycznych. Jednym z kluczowych obszarów mających strategiczny wpływ na efektywność i skuteczność działań oraz wysoką ocenę jakości pracy jest szeroko rozumiany rozwój pracowniczy, począwszy od samoświadomości potrzeby ciągłego zgłębiania wiedzy i zwiększania umiejętności zawodowych poprzez aktywne uczestnictwo w różnych formach doskonalenia zawodowego, aż po akceptację i wsparcie otrzymywane ze strony przełożonych dla rozwoju zawodowego

Celem pracy była analiza procesu kształcenia pielęgniarek i położnych w świetle wybranych danych statystycznych.
\end{abstract}

SŁOWA KLUCZOWE: pielęgniarka, położna, kształcenie.

\section{Wstęp}

Nabywanie uprawnień i wykonywanie zawodu pielęgniarki i położnej uregulowane jest zapisami podstawowego aktu prawnego, tj. ustawy z dnia 15 lipca 2011 r. o zawodach pielęgniarki i położnej [1]. Wykonywanie zadań na pielęgniarskich stanowiskach pracy polega ma udzielaniu świadczeń zdrowotnych. Ich szeroki wachlarz obejmuje: diagnozowanie warunków i potrzeb zdrowotnych pacjenta, rozpoznawanie problemów pielęgnacyjnych oraz zaplanowanie i sprawowanie opieki pielęgnacyjnej nad pacjentem, a także autonomiczne udzielanie (w pewnym określonym zakresie) świadczeń zapobiegawczo-diagnostyczno-leczniczo-rehabilitacyjnych i medycznych czynności ratunkowych. Do obowiązków należy również realizowanie zleceń lekarskich (w procesie diagnostyki, leczenia i rehabilitacji), orzekanie o rodzaju i zakresie świadczeń opiekuńczo-pielęgnacyjnych, a także podejmowanie działań z zakresu edukacji zdrowotnej i promocji zdrowia [2].

\begin{abstract}
Desirable, high quality work in medical institutions is only possible if a high level of medical services is guaranteed. One of the key areas with a strategic impact on the efficiency and effectiveness of actions and the high quality of work is broadly defined employee development - from the self-awareness of the need for continuous knowledge deepening and professional development through active participation in various forms of professional development, to acceptance and support for professional development from the supervisors.

The aim of the study was to analyze the process of nursing and midwifery education in the light of selected statistical data.
\end{abstract}

KEYWORDS: nurse, midwife, education.

Wobec potrzeby i obowiązku kształcenia i doskonalenia zawodowego należy wspomnieć, że istnieje duża dostępność form pozwalających na zdobywanie nowych lub/i pogłębienie posiadanych kwalifikacji i umiejętności zawodowych. Proces kształcenia pielęgniarek ma odzwierciedlenie w dotyczących go podstawach prawnych:

- Ustawie z dnia 15 lipca 2011 r. o zawodach pielęgniarki i położnej (Dz.U.2016.1251 j.t. z późn. zm.);

- Rozporządzeniu Ministra Zdrowia z dnia 29 listopada 2012 r. w sprawie Krajowej Rady Akredytacyjnej Szkół Pielęgniarek i Położnych (Dz.U.2012.1441);

- Rozporządzeniu Ministra Zdrowia z dnia 20 sierpnia 2012 r. w sprawie szczegółowych wymagań dotyczących kształcenia pielęgniarek i położnych (Dz.U.2012.970);

- Ustawie z dnia 27 lipca 2005 r. prawo o szkolnictwie wyższym (Dz.U.2016.1842 j.t. z późn. zm.); 
- Rozporządzeniu Ministra Nauki i Szkolnictwa Wyższego z dnia 9 maja 2012 r. w sprawie standardów kształcenia dla kierunków studiów: lekarskiego, lekarsko-dentystycznego, farmacji, pielęgniarstwa i położnictwa (Dz.U.2012.631 z późn. zm.);

- Rozporządzeniu Ministra Zdrowia z dnia 14 czerwca 2012 r. w sprawie szczegółowych warunków prowadzenia studiów dla pielęgniarek i położnych, które posiadają świadectwo dojrzałości i ukończyły liceum medyczne lub szkołę policealną albo szkołę pomaturalną, kształcącą w zawodzie pielęgniarki i położnej (Dz.U. 2012 poz. 770) [3].

\section{Podnoszenie kwalifikacji jako wskaźnik jakości pracy}

Praca odgrywa zróżnicowaną rolę w życiu człowieka, jest ona również istotna dla rozwoju osobistego i może być źródłem satysfakcji i spełnienia [4]. Rozwój pracownika jest wymaganą cechą, wywierającą wpływ na ocenę jakości pracy, ale także jest istotny dla zaspokojenia innych potrzeb. Pożądaną cechą poprawiającą jakość pracy jest możliwość podnoszenia kwalifikacji i rozwoju pracownika. Ma to na celu nie tylko kształtowanie umiejętności potrzebnych w pracy, ale także zaspokojenie innych potrzeb. Z danych Głównego Urzędu Statystycznego wynika, że w 2011 roku najliczniejsza grupa pracujących (ponad 34\%) uczestniczyła w kształceniu nieformalnym, czyli nauce niezorganizowanej, zazwyczaj samodzielnej. Nieco mniejszy odsetek (29\%) pracujących uczestniczył w kształceniu pozaformalnym. Prawie co dziesiąta osoba pracująca podnosi kwalifikacje w systemie edukacji formalnej. Co piąty spośród uczestniczących w edukacji pozaformalnej bierze udział w szkoleniach w celu poprawy jakości wykonywanej pracy lub rozwoju kariery zawodowej. Kobiety częściej niż mężczyźni uczestniczą w szkoleniach, kierując się tym czynnikiem motywacyjnym. Blisko 60\% uczestników szkoleń uważa, że nabyli przydatne umiejętności, a niemal $56 \%$ jest przekonanych, że po szkoleniu będą lepiej wykonywać obowiązki zawodowe. Udział w szkoleniach pozaformalnych ma jednak bardzo ograniczony wpływ na znalezienie nowej pracy.

\section{Analiza zasobów kadrowych ze względu na wykształcenie}

Z danych Biuletynu Statystycznego Ministerstwa Zdrowia z 2016 roku wynika, że w Polsce w 2015 r. liczba pielęgniarek uprawnionych do wykonywania zawodu wynosiła 285 431, natomiast położnych 36103 [5]. Najwyższe wskaźniki pielęgniarek na 10 tys. ludności miały województwa: świętokrzyskie, podkarpackie i śląskie (powy- żej 82), dla położnych: podkarpackie i podlaskie (powyżej 11). Natomiast najmniejsze wskaźniki na 10 tys. ludności miały w przypadku pielęgniarek województwa: pomorskie i wielkopolskie (poniżej 65), dla położnych pomorskie i warmińsko-mazurskie (poniżej 8). Liczba pielęgniarek i położnych pracujących w placówkach ochrony zdrowia w 2015 r. wynosiła odpowiednio 185860 oraz 22 051. Najwyższe wskaźniki pielęgniarek i położnych na 10 tys. ludności miały województwa: lubelskie i podkarpackie odpowiednio powyżej 55 i powyżej 6,5. Natomiast najmniejsze wskaźniki na 10 tys. ludności miały w przypadku pielęgniarek województwa: pomorskie i wielkopolskie (poniżej 42), dla położnych opolskie i zachodnio-pomorskie (poniżej 5). Liczba pielęgniarek z wyższym wykształceniem, posiadających tytuł specjalisty, wynosiła 17522 (z tego I stopnia 2869 , II stopnia 1042 i specjalności 13 611), w przypadku położnych ogólna liczba wynosiła 1 692, (w tym I stopnia 433, II stopnia 94, specjalności 1 165).

W roku 2016 Ministerstwo Zdrowia opublikowało mapy potrzeb zdrowotnych w zakresie leczenia szpitalnego. Obowiązek tworzenia regionalnych map potrzeb zdrowotnych wynika z ustawy z dnia 21 marca 2014 r. o zmianie ustawy o świadczeniach opieki zdrowotnej finansowanych ze środków publicznych oraz niektórych innych ustaw (Dz.U.2014.619). Mapy te zawierają m.in. wnioski i rekomendacje dla szpitalnictwa dotyczące oddziałów wg dziedzin medycyny [6]. Analiza zasobów kadrowych pielęgniarek i położnych w kraju, na podstawie map potrzeb zdrowotnych, wykazała, iż z uwagi na wysoki wiek prawie połowy z nich istnieje konieczność szybkiego zwiększenia ogólnej liczby pielęgniarek i położnych i położenie nacisku na „odmłodzenie” tej grupy zawodowej. Ze względu na liczbę osób po 50. roku życia wśród pielęgniarek i położnych, najmniej optymistycznie sytuacja wygląda w województwie podlaskim, warmińsko-mazurskim, lubuskim, dolnośląskim, zachodniopomorskim i kujawsko-pomorskim. Jednocześnie najmniejszą liczbę pielęgniarek w przeliczeniu na 100 tys. ludności wykazuje województwo pomorskie, zachodniopomorskie, wielkopolskie i lubuskie, zaś najmniejszą liczbę położnych w przeliczeniu na 100 tys. kobiet w wieku rozrodczym wykazuje województwo warmińsko-mazurskie, pomorskie, opolskie i mazowieckie [7].

Dodatkowo należy zauważyć, iż zbyt mała liczba pielęgniarek i położnych wykwalifikowała się w poszczególnych dziedzinach kształcenia, gdyż jest to zaledwie ok. 10\% ogólnej liczby pielęgniarek i położnych [7]. Z analizy danych dla poszczególnych województw wynika, że w 8 województwach kwalifikacje posiada mniej niż $10 \%$ pielęgniarek w tym najmniejszą wartość posiadają województwo śląskie 5,7\%, łódzkie 6\% i mazowieckie 
6,5\%. Natomiast powyżej 10\% wykazuje również 8 województw, w tym największą wartość ma województwo zachodniopomorskie 15\% i lubelskie 14\%.

\section{Dane dotyczące kształcenia pielęgniarek i położnych}

Natomiast z danych Centrum Kształcenia Podyplomowego Pielęgniarek i Położnych wynika [8], że łączna liczba specjalistów w latach 2002-2016 wynosi 39476 pielęgniarek i położnych. W tym przypadku najmniej specjalistów posiada województwo opolskie (2,5\%), świętokrzyskie $(3,1 \%)$ oraz lubuskie $(3,2 \%)$, natomiast najwięcej województwo małopolskie i mazowieckie (po $10,2 \%)$ i dolnośląskie (10,1\%). Łączna liczba absolwentów kursów kwalifikacyjnych wynosiła 136 301, z tego najwięcej było w województwach: mazowieckim (17,8\%), i śląskim (13,9\%), natomiast najmniej w województwie: lubuskim (2,3\%), opolskim i warmińsko-mazurskim (2,5\%). Łączna liczba absolwentów kursów specjalizacyjnych wynosiła 282 302, z tego najwięcej było w województwach: mazowieckim (16,1\%), i śląskim (11,1\%), natomiast najmniej w województwie: opolskim (2,3\%) i warmińsko-mazurskim (2,9\%). Łączna liczba absolwentów kursów dokształcających wynosiła 109 618, z tego najwięcej było w województwach: małopolskim $(21,6 \%)$ i mazowieckim $(20,3 \%)$, natomiast najmniej w województwach: lubuskim (1,3\%) i podlaskim (2,0\%).

Analiza szczegółowa danych Centrum Kształcenia Podyplomowego Pielęgniarek i Położnych pokazuje, że najwięcej osób kształciło się w latach 2002-2016 w zakresie pielęgniarstwa anestezjologicznego i intensywnej opieki (5394), pielęgniarstwa chirurgicznego (4894), pielęgniarstwa zachowawczego (4423) oraz pielęgniarstwa operacyjnego (3222). Natomiast najmniej osób kończyło szkolenia i kursy w zakresie promocji zdrowia i edukacji zdrowotnej dla położnych i pielęgniarek (odpowiednio 26 i 23 ).

\section{Analiza zasobów kadrowych i kształcenia pielęgniarek i położnych w województwie kujawsko-pomorskim}

Z danych opublikowanych w Biuletynie Statystycznym dotyczącym stanu ochrony zdrowia wynika, że na terenie województwa kujawsko-pomorskiego zatrudnionych było 4626 lekarzy, 659 lekarzy dentystów, 10197 pielęgniarek, 1215 położnych i 921 fizjoterapeutów [9].

Zmniejsza się liczba pielęgniarek ze średnim wykształceniem. Spowodowane jest to podejmowaniem kształcenia na poziomie akademickim [9]. Z danych wynika, że w województwie kujawsko-pomorskim liczba pielęgniarek i położnych z wyższym wykształceniem

Stan na 31.12.2015 r. wynosi: 4289 pielęgniarek i 459 położnych. Dla pielęgniarek wskaźnik na 10 tys. ludności wynosi: 20,6 dla województwa oraz 19,5 dla kraju. Dla położnych odpowiednio: 2,2 oraz 2,5. Warto podkreślić, że liczba pracowników z wyższym wykształceniem zatrudnionych w sektorze opieki zdrowotnej wzrasta z każdym kolejnym rokiem ${ }^{*}$. Pielęgniarki posiadające średnie wykształcenie (5908 osób) [9] widzą potrzebę ciągłego uzupełniania wiedzy i podwyższania kwalifikacji, ponieważ, na przestrzeni ostatnich lat widoczny jest wzrost liczby pielęgniarek zgłębiających wiedzę w ramach kursów kwalifikacyjnych (2367 osób w roku 2015) oraz w ramach specjalizacji (1043 osób w 2015 roku).

Pielęgniarki ze średnim wykształceniem, z ukończonym kursem kwalifikacyjnym (łącznie w 2015 roku 2367 osób) najczęściej wybierały kursy w zakresie: pielęgniarstwa rodzinnego (727 osób), środowiska nauczania i wychowania (311 osób), pielęgniarstwa anestezjologicznego i intensywnej opieki (297 osób), opieki długoterminowej (248 osób) oraz pielęgniarstwa ratunkowego (207 osób). Kursy w zakresie pielęgniarstwa neonatologicznego, onkologicznego i kardiologicznego ukończyła najmniejsza liczba pielęgniarek [9]. Ogólna liczna pielęgniarek z tytułem specjalisty w dziedzinie pielęgniarstwa w 2015 roku wynosiła 1043 osoby. Wśród nich jest m.in. 206 specjalistów pielęgniarstwa chirurgicznego, 161 osób uzyskało specjalizację z pielęgniarstwa zachowawczego, 130 z pielęgniarstwa anestezjologicznego i intensywnej opieki, 113 z pielęgniarstwa operacyjnego oraz 104 w zakresie opieki długoterminowej.

Z danych Centrum Kształcenia Podyplomowego Pielęgniarek i Położnych wynika, że w województwie kujawsko-pomorskim łączna liczba specjalistów w latach 2002-2016 wynosiła 2 763, łączna liczba absolwentów kursów kwalifikacyjnych - 136 301, kursów specjalizacyjnych - 282302 oraz kursów dokształcających - 109618 [10].

\section{Podsumowanie}

W perspektywie finansowej 2007-2015 Ministerstwo Zdrowia (Departament Pielęgniarek i Położnych) realizowało dwa projekty systemowe w zakresie dotyczącym pielęgniarek i położnych, współfinansowane z Europejskiego Funduszu Społecznego w ramach Programu Operacyjnego Kapitał Ludzki [11]. Pierwszy z nich, realizowany w latach 2008-2015, to projekt systemowy pn. „Kształcenie zawodowe pielęgniarek i położnych w ramach studiów pomostowych”. Drugi, realizowany z Centrum Medycznego Kształcenia Po-

\footnotetext{
" Dane dotyczą pracujących, dla których jednostka (resort zdrowia, resort obrony narodowej) jest głównym miejscem pracy.
} 
dyplomowego w latach 2012-2015, to projekt systemowy pn. „Wsparcie systemu kształcenia ustawicznego personelu medycznego w zakresie opieki geriatrycznej”, współfinansowany ze środków Europejskiego Funduszu Społecznego w ramach Programu Operacyjnego Kapitał Ludzki.

W perspektywie finansowej 2014-2020 Ministerstwo Zdrowia realizuje projekt pozakonkursowy pn. „Rozwój kompetencji pielęgniarskich”, współfinansowany z Europejskiego Funduszu Społecznego w ramach Programu Operacyjnego Wiedza Edukacja Rozwój [11]. Celem projektu jest poprawa jakości kształcenia na kierunkach pielęgniarstwo i położnictwo oraz wypracowanie mechanizmów umożliwiających zwiększenie liczby pielęgniarek i położnych w Polsce.

Przykładem stwarzania możliwości kształcenia jest m.in. Centrum Kształcenia ZDZ w Poznaniu, które proponuje atrakcyjne warunki korzystania ze szkoleń i kursów dla pielęgniarek i położnych [12]. Zaprasza do udziału w projekcie „Doskonalenie kadr medycznych. Kursy kwalifikacyjne i specjalistyczne dla pielęgniarek i położnych". Kursy są współfinansowane przez Unię Europejską w ramach Europejskiego Funduszu Społecznego, w ramach działania 5.4 Kompetencje zawodowe i kwalifikacje kadr medycznych, Programu Operacyjnego Wiedza Edukacja Rozwój. Celem tego projektu jest podniesienie kwalifikacji zawodowych 4030 pielęgniarek i położnych z terenu 8 województw: (dolnośląskie, kujawsko-pomorskie, lubuskie, łódzkie, opolskie, śląskie, wielkopolskie, zachodniopomorskie) w zakresie dziedzin związanych z potrzebami epidemiologiczno- -demograficznymi kraju. Realizacja projektu zaplanowana jest na lata 2016-2018 i odbywać się będzie równocześnie w kilku województwach.

Pożądana, wysoka jakość pracy w podmiotach działalności leczniczej możliwa jest do osiągnięcia tylko wówczas, gdy zagwarantowany zostanie wysoki poziom świadczonych usług medycznych. Jest to warunek konieczny, ale nie niemożliwy. Jednym z kluczowych obszarów mających strategiczny wpływ na efektywność i skuteczność działań oraz wysoką ocenę jakości pracy jest szeroko rozumiany rozwój pracowniczy, począwszy od samoświadomości potrzeby ciągłego zgłębiania wiedzy i zwiększania umiejętności zawodowych poprzez aktywne uczestnictwo w różnych formach doskonalenia zawodowego, aż po akceptację i wsparcie otrzymywane ze strony przełożonych dla rozwoju zawodowego (bogaty wachlarz szkoleń przygotowany przez pracodawcę, urlopy szkoleniowe, ścieżki kariery zawodowej przewidujące awanse dla osób ustawicznie kształcących się). Działania te z pewnością wpłyną motywująco na pracowników, ale także będą wymiernym wkładem dla rozwoju i prestiżu podmiotu działalności leczniczej.

\section{Piśmiennictwo}

1. Ustawa z dnia 15 lipca 2011 r. o zawodach pielęgniarki i położnej (Dz.U.2016.1251, z późn. zm.).

2. http://www.mz.gov.pl/system-ochrony-zdrowia/kadra-medyczna-i-ksztalcenie/pielegniarki-i-polozne/ [data wejścia: 10.11.2016 r.].

3. http://www.mz.gov.pl/system-ochrony-zdrowia/kadra-medyczna-i-ksztalcenie/pielegniarki-i-polozne/ksztalcenieprzeddyplomowe-pielegniarek-i-poloznych/ [data wejścia: 10.11.2016r.].

4. http://stat.gov.pl/obszary-tematyczne/rynek-pracy/ opracowania/wskazniki-jakosci-pracy,10,1.html s. 20. [data wejścia: 10.11.2016r.].

5. Biuletyn statystyczny Ministra Zdrowia https://www.csioz. gov.pl/statystyka/biuletyn-statystyczny/ [data wejścia: 10.11.2016r.].

6. http://www.rynekzdrowia.pl/Finanse-i-zarzadzanie/ Ministerstwo-Zdrowia-publikuje-mapy-potrzebzdrowotnych-w-szpitalnictwie,161494,1.html [data wejścia: 10.11.2016r.].

7. http://www.rynekzdrowia.pl/Finanse-i-zarzadzanie/ Ministerstwo-Zdrowia-publikuje-mapy-potrzebzdrowotnych-w-szpitalnictwie,161494,1.html (Źródło danych: Naczelna Izba Lekarska, Naczelna Izba Pielęgniarek i Położnych, GUS). [data wejścia: 10.11.2016r.].

8. http://www.ckppip.edu.pl/poziome-menu/opracowania-ianalizy/dane-statystyczne-ksztalcenia.html [data wejścia: 10.11.2016r.].

9. http://www.zdrowie.bydgoszcz.uw.gov.pl/pliki/ statystyka/opracowania/biuletyn/2015/BIULETYN\%20 STATYSTYCZNY\%202015.pdf s.184 [data wejścia 17.11.2016r.].

10. http://www.ckppip.edu.pl/poziome-menu/opracowania-ianalizy/dane-statystyczne-ksztalcenia.html [data wejścia: 10.11.2016r.].

11. http://www.mz.gov.pl/system-ochrony-zdrowia/kadramedyczna-i-ksztalcenie/pielegniarki-i-polozne/projektysystemowe/ [data wejścia: 10.11.2016r.].

12. http://cdkm.zdz.poznan.pl/ [data wejścia: 10.11.2016r.].

Artykuł przyjęty do redakcji: 28.11.2016

Artykuł przyjęty do publikacji: 15.12.2016

Źródło finansowania: Praca nie jest finansowana z żadnego źródła. Konflikt interesów: Autorzy deklarują brak konfliktu interesów.

Adres do korespondencji:

Renata Rasińska

ul. Mariana Smoluchowskiego 11

60-179 Poznań

tel.: 618612254

e-mail: rasinska@ump.edu.pl

Zakład Organizacji i Zarządzania w Opiece Zdrowotnej

Uniwersytet Medyczny im. Karola Marcinkowskiego w Poznaniu 